Eixo Roda, Belo Horizonte, v. 28, n. 3, p. 41-64, 2019

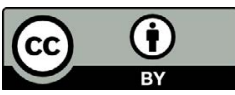

\title{
A pátria no palco: mobilização política e construção de uma identidade nacional nos clubes recreativos italianos em São Paulo (1870-1920)
}

\section{Motherland on Stage: Political Mobilization and Construction of a National Identity in Italian "Philodramatic" Societies in São Paulo (1870-1920)}

\author{
Alessandra Vannucci \\ Universidade Federal do Rio de Janeiro (UFRJ), Rio de Janeiro, Rio de Janeiro / Brasil \\ alevannucci@gmail.com
}

Resumo: $\mathrm{O}$ ensaio analisa a atividade dos clubes recreativos italianos em São Paulo, a partir do final do século XIX, quando a cidade se transforma de vila colonial em metrópole industrial e sofre o impacto das grandes migrações. A fuga dos trabalhadores das plantações para a cidade, onde conseguem articular formas de resistência à exploração através do associacionismo voluntário (jornais, sindicatos e teatro) alimenta um clima de discriminação, culminando em perseguição racial. A emancipação política é conquistada através da arte, principalmente nos palcos. Nas peças deste repertório, os valores patrióticos e nacionalistas do Risorgimento, que haviam alimentado uma primeira fase da literatura emigrante, são paulatinamente substituídos pela utopia internacionalista da sociedade "sem pátria e sem patrões".

Palavras-chave: teatro italiano no Brasil; amadorismo teatral; emigração.

Abstract: We analyze some of the Italian recreational clubs activities in São Paulo, from the end of the $19^{\text {th }}$ century, when the city was transformed from a colonial village into an industrial metropolis and suffered the impact of the great migrations. Escaping from plantation to the city, workers manage to articulate forms of resistance to exploitation through voluntary associations (newspapers, trade unions and theatre) which fuels a discrimination atmosphere, culminating in racial persecution. Political emancipation has been pursued through art, especially on stage. The patriotic and nationalist values of the 
Italian Risorgimento that had fuelled a first phase of emigrant literature are gradually replaced by the internationalist "homeless and boss less" society utopia.

Keywords: Italian theatre in Brazil; amateur actors; emigration.

Desde o início das guerras civis pela independência italiana, que perduraram durante meio século culminando na proclamação do Reino (1861), o Brasil, assim como Argentina e Uruguai, acolheu italianos envolvidos nas insurreições, alguns sob ameaça de sentença capital (como Giuseppe Garibaldi e Gian Battista Cuneo) que embarcavam clandestinamente no porto de Gênova para qualquer destino sulamericano. Foi do outro lado do oceano que os exilados realizaram suas missões de proselitismo, acompanhando por carta as tentativas de libertar a península dos exércitos de ocupação distribuídos e protegidos pela Santa Aliança após o Congresso de Viena (1814) que visava restaurar e manter o poder das nações vencedoras. Antes disso, o breve intervalo de Reino da Itália (1805-1814) havia fortalecido na população um sentimento de "nação", mesmo que vago e idealista, considerando o histórico plurissecular de divisão que a Restauração reconfirmava. Os Bourbon dominavam as regiões do Sul desde a Revolução Francesa, em dois reinos (Napoli e Sicília) reunidos pelo Congresso de Viena no Reino das Duas Sićlias; enquanto no Norte, regiões tradicionalmente independentes como Lombardia e Vêneto (incluindo a antiga e desde sempre autárquica República de Veneza) foram anexadas ao Império Austríaco. A República de Gênova, que contava com sete séculos de autogoverno e com os maiores bancos da Europa, foi cedida ao Reino de Sardenha, dominado pela família de Saboia. A utopia de livrar e reunir a Itália, que recebeu nome de Risorgimento - vale dizer "nova insurgência", invocando uma segunda onda revolucionária que revertesse a Restauração - alimentava as lutas independentistas.

No Brasil, a repentina proclamação da Independência, em 1822, havia mostrado aos exilados italianos a possível realização de algo que permanecia frustrado em sua terra natal. Entretanto, a aliança da família de Orleans e Bragança com os Bourbons, selada em 1843 pelo casamento entre o Imperador Pedro II e a princesa Teresa Cristina, que um ministro do Reino das Duas Sicílias negociou em Viena, motivava a aversão dos exilados italianos ao governo imperial. Por outro lado, a união facilitou a chegada ao Brasil de imigrantes oriundos do Reino 
(especialmente da Campania e da Calábria) sob a proteção da Imperatriz (CAPPELLI, 2014).Os Bourbons foram expulsos da Itália em 1860, por ação conjunta do exército do Reino de Sardenha e das tropas de Garibaldi - os mil soldados voluntários que vestiam a camisa vermelha característica dos militantes garibaldinos desde a Legião Italiana, ou seja, a armada reunida por Garibaldi em Montevidéu em 1842 e que o seguiu em seu aventurosíssimo retorno à Itália. A unificação deu início ao Reino da Itália (1861). Os êxitos da guerra civil na península, portanto, interessavam de perto à família imperial brasileira, inclusive causando as agendas separadas das S.S.M.M. (Suas Majestades) nas viagens à Itália após 1861, quando era exigida a presença do Imperador em eventos da Corte dos Saboia, aos quais a Imperatriz recusava terminantemente comparecer (VANNUCCI, 2005).

Ao longo do século, o fluxo de migrantes aumentou de algumas centenas para milhares, mesmo depois de proclamada a unificação em 1861. Foram milhões a partir da década de 70 , quando os portos norteamericanos começaram a limitar os ingressos. 'Já não viajavam sozinhos e clandestinos, mas com a família, acuados por carestias e desemprego a vender tudo que possuíam e tentar a sorte no outro mundo. As partidas eram épicas, longamente preparadas e muitas vezes sofridas. Desistiam de seu negócio (eram sapateiros, músicos, cozinheiros, barbeiros, marceneiros, agricultores, mas raramente médicos e jornalistas) para se adaptar a qualquer serviço ou adaptando o ofício ao exercício na rua. Alguns se tornavam tocadores de realejo ou caixeiros, outros eram reduzidos a mendicância. Mas os atraía a miragem de uma segunda vida em um país novo, independente e lançado em corrida febril rumo ao progresso. Era a fabulosa Merica, onde tudo poderia acontecer para quem ousasse partir a sua conquista (VANNUCCI, 2012).

No Brasil, por onde uma colônia italiana se instalasse, surgia um jornal militando pela civilização, palavra em que se resumiam as ideias libertárias do Risorgimento e a fé em um futuro universal regido pela livre informação, pelo progresso e as belas artes. Aliás, "civilização" era palavra recorrente no observatório político promovido pelos refugiados, para os quais o Brasil não só era nação livre de exércitos estrangeiros,

\footnotetext{
${ }^{1}$ Entre 1880 e 1924 entraram nos portos brasileiros 3,6 milhões de emigrantes, dos quais $38 \%$ italianos. Era o terceiro país mais escolhido para emigrar, após Estados Unidos e Argentina.
} 
como também prometia se tornar livre da escravidão e da censura. Inumeras publicações em língua italiana gritavam sua militância na primeira página, como La giustizia, Garibaldi, Risorgimento, Motore Italiano, La Battaglia, La Difesa, Primo Maggio, L'Italia, Gli schiavi bianchi, Avanti! Quase todas efêmeras, na maioria varridas pelos fuzis da polícia e do exército imperial.

O Brasil acolhia os emigrantes, mas não suas eventuais ideias revolucionárias. Um precoce sintoma do perigo que os italianos poderiam comportar para um Brasil livre, mas nem um pouco libertário foi o assassinato de Giovan Battista Badaró, um jovem jornalista formado em Medicina, originário da Ligúria e naturalizado brasileiro, durante uma manifestação em São Paulo em novembro de 1830. O apelido "Libero" testemunhava suas ideias republicanas. No enterro, houve tumulto. Firmou-se a fama de traidora para a cidade que "devia ser a segunda casa de muitos como ele" (COMEMORAÇÃO..., 1897, p. 2).

$\mathrm{O}$ fermento abolicionista amadureceu somente cinquenta anos mais tarde, quando os fazendeiros, sob ameaça de perder o lucro das plantações de café, garantido pela exploração escravagista, começaram a defender o emprego de mão de obra não escrava. Pareceria até um princípio liberal se não fosse que, pressionados pela carência de trabalhadores, os importavam de fora, aproveitando de subsídios disponibilizados pelo governo imperial. ${ }^{2}$ As campanhas de recrutamento eram confiadas a agentes encarregados das companhias de navegação que ganhavam uma comissão por cabeça recrutada. Propagandas mostrando os perfis azuis dos transatlânticos e as imensas planícies verdes da América Latina preenchiam os muros das estações de trem e marítimas; enquanto aos hóspedes dos hotéis e nos intervalos das óperas era oferecida uma taça de café brasileiro acompanhado de panfletos sobre as condições bucólicas de trabalho nas plantações (HUTTER, 1986, p. 27). Na compra da passagem, multidões de analfabetas se comprometiam também a honrar contratos de futuro emprego, ignorando as condições vexatórias que passavam a valer uma vez desembarcados e despachados para fazendas longínquas.

\footnotetext{
${ }^{2}$ Os subsídios perduraram até 1902, quando o governo italiano, ciente dos abusos aos quais os imigrantes eram submetidos, emitiu um decreto que proibia a emigração subsidiada ao Brasil (TRENTO, 1989, p. 5). A partir desta data, o fluxo migratório diminuiu consistentemente.
} 
O sonho de uma segunda vida na América proporcionou, assim, a autoescravização involuntária da massa imigrante e, como corolário, acumulou uma enorme reserva de braços para a indústria que então se instalava em São Paulo. Além dos recém-chegadas no porto de Santos, nela afluíam os migrantes que fugiam das fazendas em busca de melhores condições de vida. Entre 1887 e 1900, São Paulo recebeu pouco menos de um milhão de estrangeiros, dos quais mais de 600 mil italianos, com 90 mil espanhóis, 80 mil portugueses, 18 mil austríacos e 20 mil de outras nacionalidades (COSTA; DE BONI, 1987). Contando com 31 mil habitantes oficialmente registrados em 1872, a cidade alcançou 150 mil em 1895 e meio milhão em 1920. No censo demográfico realizado neste ano, $84 \%$ da população paulista era italiana de nascimento ou de primeira geração; desta, um quinto afirmava-se empregada em alguma atividade industrial (BASSANEZI, 1999). Ao crescimento exponencial do número de imigrantes corresponde sua integração à sociedade civil e, por consequência, a remodelação urbanística de São Paulo, que perdia as características provincianas da vila colonial e adquiria as características tentaculares da metrópole industrial.

Na parte da cidade situada acima do rio Tietê surgiam os ecléticos casarões da Avenida Paulista. Entre o rio Tietê e o rio Tamanduateí passava a estrada de ferro e os empresários preferiam instalar suas fábricas e os alojamentos dos operários nos bairros Barra Funda e Belenzinho (CARELLI, 1985, p. 34). Daí até as margens da cidade se estendiam os bairros-dormitórios onde os imigrantes se distribuíam por famílias e reproduziam hábitos de convivência e construções das regiões de origem. Tradicionalmente, vênetos iam para o Bom Retiro, napolitanos para o Brás e a Mooca e calabreses para o Bexiga (CAPPELLI, 2014; TRENTO, 1989, p. 12). Neste último, um dos bairros mais insalubres (digno do nome "bexiga") e com a maior densidade populacional, as habitações familiares dos italianos "se encontravam ao lado dos miseráveis cortiços dos negros, antigos escravos marginalizados na sociedade paulista" (MARZOLA, 1979, p. 81).

Mesmo oriundos de regiões diversas da península - sendo, portanto, estrangeiros entre si nos usos e nos dialetos - os italianos traziam algum legado comum. Eram católicos; todos comiam pão (ou melhor, pizza, que impera no cardápio dos restaurantes paulistas desde 1880) sendo que, para o restante da alimentação, sobrava a designação genérica de companatico; e faziam teatro. 
Em um salão vazio, no piso térreo de uma casa em qualquer cruzamento daqueles bairros caoticamente urbanizados, eles organizavam festas aos sábados, com programas agradáveis para todas as idades: canções em dialeto, espetáculo, rifa gastronômica, banda, blocos, bingo, saraus e o inevitável baile familiar para terminar a noitada bem depois da meia noite. Além de abrigar um tablado para uso da respectiva companhia amadora (Circolo Filodrammatico), os salões podiam servir de academia e sede de associação desportiva - tais como a Palestra Itália, primeiro clube paulista de futebol, que deu origem ao Palmeiras. As Sociedades de Ajuda Mútua (Società di Mutuo Soccorso), como eram chamados os clubes que administravam tais salões, ofereciam também assistência médica, legal e uma orientação para os recém-chegados. ${ }^{3}$

Distribuídas em rede, as Sociedades conectavam as margens e as populações marginais da cidade, oferecendo densa agenda semanal de eventos. Tendo uma maioria étnica no bairro, defendiam certa tipicidade regional e celebravam o padroeiro da comunidade de origem com intuito de competir com a festa do santo do bairro vizinho. Após a Unificação, promoviam atos de respeito à nova bandeira italiana, sem abandonar, contudo, o culto ao estandarte do clã. Pois, além de religião, pão e palco, os italianos traziam o legado de antigos antagonismos e um temperamento ufanista capaz de estimular divisões em um contexto político no qual era de se auspiciar, pelo contrário, a união solidária entre trabalhadores. Era tarefa árdua organizar a luta de classe entre eles, sendo que mal se compreendiam.

A composição naturalmente internacionalista dos trabalhadores em São Paulo, por um lado, facilitava a organização corporativa de sindicatos por categoria; por outro lado, impedia a participação massiva em qualquer programa político que necessitasse de consenso - tal como uma greve, uma reinvindicação coletiva, um posicionamento eleitoral porque a discriminação étnica tendia a prevalecer sobre a causa comum. "Alemães, russos, turcos, polacos, espanhóis, portugueses e, pior de todos, nós italianos: cada nação defende só a si mesma", lamenta um sindicalista italiano discursando em Primeiro de Maio no periódico $I l$

\footnotetext{
${ }^{3}$ A primeira Sociedade Italiana de Beneficência e Mútua Ajuda foi fundada pela Imperatriz Teresa Cristina em 1854, no Rio de Janeiro. Assistia os imigrantes italianos recém-chegados, oferecendo oportunidades de trabalho, acesso a saúde e educação. Em São Paulo, eram 98 em 1897, 170 em 1908, baixando para 91 em 1923.
} 
Pungolo em 01 de maio de 1909. Os italianos eram "pior de todos" porque, mesmo "a Itália já sendo unida, livre e independente, eu continuo piemontês e tu, toscano, vocês sicilianos, calabreses e vênetos; nós nem sequer entendemos uns aos outros". ${ }^{4}$

Além dos preconceitos regionais, o analfabetismo, seja na língua italiana como na portuguesa, era causa de uma impotência da qual se aproveitavam os patrões, porque a grande maioria dos imigrantes, desconhecendo seus direitos (ao ponto que desistiam da cidadania que lhes foi concedida, desde 1889 , por naturalização) se reduziam a analfabetos políticos. "Eles não estão nem aí e não querem saber nada da terra onde vivem, porque dizem que não são daqui". ${ }^{5}$ Jornais e teatro, sendo os únicos meios disponíveis de informação, acabavam desempenhando um papel bem mais amplo do que apenas diversivo: eram ferramentas pedagógicas às quais se confiava a emancipação do povo. O teatro funcionava especialmente para os iletrados ou recémchegados que não entendiam italiano nem português, apenas seu próprio dialeto. Pressionados pela urgência de comunicar na nova pátria, os imigrantes, oriundos de todos os cantos da península, descobriam serem italianos e se identificavam um pouco mais com a pátria de origem. Jornais e clubes promoviam este processo, que acabava confluindo no mais amplo processo da identidade brasileira em construção. No debate sobre o que aceitar e o que excluir da tal verdadeira brasilidade, contradições emergiam. A realidade do país negava a visão utópica de pátria acolhedora, frustrando expectativas excessivas e embalando lembranças idealizadas da pátria abandonada.

$* * * * *$

As razões e contradições que faziam brotar tons patrióticos no trabalho dos atores amadores (que traduz o italiano filodrammatici) animavam também a proposta nacionalista que, a cada primavera, viajava

\footnotetext{
${ }^{4}$ Todos trechos citados nesse parágrafo foram extraídos da obra de Hall (2004), sem que fosse possível recuperar outras informações de referência, exceto que foram publicados originalmente no jornal Il Pungolo em 01 de maio de 1909.

${ }^{5} \mathrm{O}$ trecho citado foi encontrado na obra de Hall (2004), sem que fosse possível recuperar outras informações de referência, exceto que foi publicado originalmente no jornal Amigo do povo em 06 de dezembro de 1903.
} 
nos baús de mattatori e primedonne, isto é, divos e divas do teatro italiano da época que embarcavam nos transatlânticos e enfrentavam longas e perigosas travessias oceânicas para apresentar seu repertório do outro lado do mundo. Estas turnês sazonais na América Latina contavam com lucros fabulosos e com a torcida fanática dos oriundos, além de constituir uma tática de fuga da baixa temporada italiana. Aos viajantes convinha apresentar tais empreitadas transoceânicas como missões patrióticas cujas glórias, narradas em pormenores na imprensa mundial, repercutiam como justo reconhecimento do gênio italiano. De volta à pátria, atores e atrizes capitalizavam a consagração "mundial" assim obtida, aumentando seu cachê e multiplicando a receita da bilheteria. Assim, foi graças a tais cidadãos de existência mambembe que a Itália recém-fundada se projetou no novo mundo como nação de sólida e unitária cultura (VANNUCCI, 2003).

Até a virada de século, São Paulo não tinha estrutura para oferecer aos divos de passagem a pompa proporcionada pelas grandes capitais, como Buenos Aires e Rio de Janeiro, pois dispunha de apenas um teatro: o Theatro São José, inaugurado em 1865 (seguirá o Politeama, em 1892 e o Teatro Municipal, em 1907). Sobravam pouquíssimas datas na pauta do São José, lotada de óperas, operetas, revistas e festas folclóricas; mesmo assim, acolheu a conceituada atriz Adelaide Ristori, dita "rainha dos palcos"; Ernesto Rossi, que Garibaldi em pessoa (o herói dos dois mundos) elogiou por carta como "ator dos dois mundos"; o grande ator republicano Tomaso Salvini. Três vezes na última década do século passou por ele o predileto das plateias, Giovanni Emanuel; e ainda Enrico Cuneo, Andrea Maggi, Ermete Novelli; sem contar atores de segundo escalão (como Roncoroni e Marietta Tiozzo) que em São Paulo fecharam contratos para papéis protagonistas, capitalizando a simples vantagem de serem italianos. Nos palcos, o italiano era língua franca. Em 1899, durante a turnê da Companhia de Óperas Cômicas vinda da capital e recitando em português, o repórter do Estado de São Paulo se alegrou por ter "finalmente conseguido ouvir um pouco de português no nosso Teatro São José: algo tão raro que temos que nos alegrar". ${ }^{6}$ Não surpreende que em sua primeira temporada o Teatro

\footnotetext{
${ }^{6} \mathrm{O}$ trecho citado foi encontrado na obra de Magaldi \& Vargas (2000, p. 23), sem que fosse possível recuperar outras informações de referência, exceto que foi publicado originalmente no jornal Estado de São Paulo.
} 
Municipal tenha contabilizado 22 companhias estrangeiras, das quais 11 italianas atuando na língua materna (sem legendas). Ao que parece, a língua italiana constituía um território compartilhado por grupos sociais que, no mais, pouco comungavam na geografia segregada da cidade. A tipicidade linguística do carcamano com seu gromelô ítalo-paulista e sua gesticulação exagerada povoava as ruas, dando uma tinta pitoresca ao panorama indistinto da metrópole e penetrando no imaginário popular. Por volta de 1865, um tal de Donato Severini lançou um empreendimento de aluguel de carruagens no Largo Paissandu que em breve se multiplicou em oito postos, espalhados pela cidade. Um dos caixeiros se passava por Garibaldi em pessoa, alimentando a saga do herói com anedotas que confidenciava aos boêmios, levando-os para casa ao amanhecer com sua carruagem (MAURO, 1980, p. 159).

Os clubes celebravam a independência italiana todo dia 20 de setembro, com a encenação da peça Sbarco dei Mille a Marsala. Cada alusão anti-imperialista despertava o entusiasmo do público, que chegava ao delírio quando Garibaldi entrava em cena. Os nomes dos clubes homenageavam seus feitos (Circolo Stella d'Italia, Unione Italiana XX settembre, Circolo d'onore Breccia di Porta Pia) e até mesmo sua data de aniversário (Circolo 24 de Junho) caindo, por sorte, no dia de São João, padroeiro de diversas cidades italianas e brasileiras. Ainda, os clubes homenageavam patriotas dados às artes (Felice Cavallotti, Paolo Ferrari, Leopoldo Marenco, Giovanni Bovio) e artistas militantes (Paolo Giacometti, Gustavo Modena, Vittorio Alfieri). Raramente aparecia um nome sem compromisso ideológico (Circolo Eleonora Duse, L'amore dell'arte). Assim como os atores viajantes, também os imigrantes amadores encenavam, ao mesmo tempo, um texto e uma nação. Paradoxalmente, faziam questão de exibir sua contribuição à missão da unificação da terra de origem enquanto se radicavam em outra terra.

A assimilação se daria por meio de uma reciclagem crítica dos valores nacionalistas herdados do Risorgimento e na elaboração de uma nova essência ítalo-paulista que pudesse espelhar o caráter híbrido ao mesmo tempo nostálgico e pioneiro, primitivista e modernista - da cultura urbana. A presença de um carcamano nativo como Juó Bananère (pseudônimo de Marcondes Machado) entre os escritores modernistas mostra a ambição de introduzir esta tipicidade ítalo-paulista na cultura letrada, como autentica voz "brasileira" capaz de refletir a modernidade com seu poderoso hibridismo linguístico. Os Gaetanino, Gennarino, 
Beppino, Carmela e outros moços e moças intalianos exibem seus vestidinhos de cores berrantes e sua gramática pouco castiça nos contos de Alcântara Machado que mitologizam, sem o menor tom de caricatura, a nova cartografia da cidade (Brás, Bexiga e Barra Funda). O mesmo, após a polêmica visita de Marinetti em 1926, provocou os modernistas da revista Terra roxa e outras terras de que importar "fórmulas modernas" serviria somente para quem quisesse "adaptá-las ao nosso solo e ao admirável idioma ítalo-pau-brasil", 7 inventado na cidade baixa multirracial e trabalhadora. "Abrasileiremos o teatro brasileiro. Melhor: apaulistanizemo-lo. Fixemos no palco o instante radioso da febre e do esforço que vivemos". ${ }^{8}$ Bem o compreende Tranquillo Zampinetti, protagonista do conto "Nacionalidade" (na coletânea citada) quando, para favorecer os negócios da família, resolve abdicar de certos aspectos nostálgicos de seu sentimento patriótico, como a leitura em voz alta dos proclamas de guerra e a obsessão de regressar à península.

Não surpreende que a partir dos anos 90, quando a unificação da Itália já havia se tornado data comemorativa e não havia mais família imperial no Brasil, o repertório dos clubes manifeste tal evolução ideológica. Deixando de reivindicar a Pátria como utopia de justiça e liberdade de um povo e de um país contra os exércitos estrangeiros, as peças dos amadores gradativamente adotaram postura de afirmação de justiça e liberdade como direitos universais, não só de um povo ou de um país. O ideal socialista da luta de classe, não distante do ideal anarquista da sociedade sem classes, ambos internacionalistas, suplantavam os valores nacionalistas que haviam animado o Risorgimento. Garibaldi não deixava de ser referência - pois sua luta pela liberdade havia sido primeiramente independentista e anti-imperialista; ${ }^{9}$ em seguida havia protagonizado, enquanto republicano, a missão da Unidade Italiana; chegando na maturidade a elaborar um ideal federalista que divulgava em seus discursos e viagens pela Europa. De modo que poderia se afirmar que, mesmo combatendo guerras nacionalistas, Garibaldi sempre

\footnotetext{
${ }^{7}$ Publicado originariamente no número 6 da revista Terra roxa e outras terras (São Paulo, jul. 1926), p, 4, e recolhido em MACHADO (2009, p. 335).

${ }^{8}$ Ver a nota de rodapé anterior.

${ }^{9}$ No Brasil, antes de participar como comandante da Revolução dos Farrapos, havia sido corsário: com sua pequena embarcação depredava navios batendo bandeira austríaca e brasileira na Baia de Guanabara.
} 
vislumbrara um mundo livre de impérios e de fronteiras nacionais. Outro personagem importante no pantheon dos trabalhadores imigrados, Giuseppe Mazzini, auspiciava o pacto da fraternidade universal - vale dizer, uma confederação de "nações irmãs" para alcançar a qual seria necessário que os povos conquistassem, antes, sua nacionalidade. Em 1835, Mazzini entendia por "nacionalidade" o livre exercício de soberania, ou seja, a consciência política de uma comunidade decidindo como deseja governar/ser governada "sob um comum direito e para um mesmo fim" (MAZZINI, 1906). No fim da vida, entretanto, ele foi empurrado em posição reacionária dentro do próprio movimento, que havia conseguido a Unidade, só que sob o jugo de uma casa real estrangeira (Saboia) e virou alvo de ataques ideológicos por parte de Bakunin, ${ }^{10}$ líder do insurgente movimento internacionalista na Itália. $\mathrm{Na}$ ótica internacionalista, o conceito de pátria era uma crença arcaica à serviço da ordem burguesa, que assim legitimava a perpetuação de exércitos sanguinários e das grandes posses.

A luta socialista rumo à sociedade sem classes fazia com que os trabalhadores que frequentavam os clubes amadores absorvessem facilmente conceitos anarquistas. Proletários de todos os países deveriam lutar juntos contra a opressão, não só capitalista. Labutar dezesseis horas por dia para enriquecer um patrão, obedecer às leis de um governo, confessar seus pecados a um padre eram consideradas obrigações impostas por regimes opressores, que não mais existiriam na sociedade "sem pátria nem patrão". Anarquistas de fama internacional como Oreste Ristori e Gigi Damiani, ambos aportados ao Brasil após fugir das cadeias italianas, davam palestras nos clubes; seus discursos inflamados agitavam muitas mentes. Porém, ficaram pouco tempo em São Paulo - foram deportados. ${ }^{11}$ Dando suporte à ação da polícia dos dois países, o governo brasileiro em 1907 decretou a expulsão imediata de estrangeiros réus de qualquer crime, seguindo modelo da lei argentina

\footnotetext{
10 "Risposta di un internazionalista a Mazzini" (1871), escrito por Mikhail Bakunin, foi publicado na revista Gazzettino rosa em 14 de agosto de 1871 e então republicado em francês no mesmo mês em La Liberté (Bruxelles, 18 ago. 1871), sendo divulgado entre democráticos da Europa inteira.

${ }^{11}$ Ristori aportou em 1904, fundou o jornal La battaglia e fugiu para Buenos Aires em 1912; em 1919 foi preso e repatriado; Damiani, chegado em 1897, viveu quinze anos em São Paulo antes de ser extraditado.
} 
de 1902 que buscava se livrar da responsabilidade dos conflitos sociais, culpando agitadores sistematicamente descritos por "alienígenas". Uma comunidade anarquista transnacional, fomentada pela mobilidade de algumas figuras especialistas, vinha alimentando projetos paralelos de modernização que interferiam nas normativas e nos fatos locais.

Ao abrir a cortina no novo século, muitos clubes eram manifestamente anarquistas e hospedavam seções de sindicato, no modelo italiano das Case del popolo. Os nomes declaravam a tendência, passando a indicar a categoria de trabalhadores que frequentava o local e promovia as suas atividades (Lega Lavoranti dei Veicoli, Lega Lavoranti del Legno, Associazione delle Classi Laboriose).

$* * * * *$

Quem promovia as atividades dos clubes? Sujeitos alfabetizados, amparados em profissões (tipógrafo, sapateiro, estaleiro, carpinteiro) que lhe proporcionavam condições de vida pequeno-burguesa e algum tempo livre a ser dedicado ao associacionismo. Mais raramente, profissionais liberais (médicos, advogados) os quais, tendo acesso à imprensa, estariam em posição favorável para orientar o movimento cultural. Nos jornais, entre os temas atuais e a crônica urbana, as peças em cartaz eram comentadas e divulgadas. Nas peças, temas oportunos ao debate político do momento eram tratados, sendo precedidas por um discurso de palestrante convidado, sobre temas sociais da atualidade como a questão operária, a condição feminina, a política italiana, a revolução russa etc. (LESSA MATTOS, 2002, p. 116). Se um clube apresentasse trabalho inconsistente do ponto de vista político, poderia ser julgado um tanto deslocado "uma vez que em nada contribuía para a instrução do povo ou propaganda". ${ }^{12} \mathrm{O}$ repertório era tirado em grande parte da dramaturgia romântica europeia de cunho realista como Morte Civile, de Giacometti, que trata o tema do divórcio. Não eram infrequentes peças com apelo melodramático, como Pia de Tolomei, de Carlo Marenco (cuja heroína é vítima da guerra fratricida) e Uma vítima inocente, de Ulisse Mengrossi (cujo herói Cesare Locatelli é assassinado pelo carrasco do Estado

${ }^{12}$ O amigo do povo (02 ago. 1902), acerca de Una notte a Firenze, de A. Dumas, encenado pela Lega Resistenza tra Cappellai no Círculo Andrea Maggi, localizado no Cassino Paulista (VARGAS, 1980, p. 48). 
Pontifício, fato histórico de 1861). ${ }^{13}$ Incontáveis as adaptações de $O s$ Miseráveis, de Victor Hugo. Raras as peças não catalogáveis no cânone realista nem melodramático, como as comédias de Shakespeare, as tragédias de Alfieri (especialmente Mirra) e de Giacometti (especialmente Maria Antonietta) e a produção naturalista moderna (apenas Ibsen, com Os espectros). Todo o processo de produção e recepção parece entender a arte como um direito ao entretenimento e uma ferramenta de propaganda política: objetivos que aquele repertório cumpria com eficácia, sem fazer falta o entretenimento. De vez em quando estreava-se um drama inédito escrito por autor italiano, ítalo-brasileiro ou estrangeiro (veja-se Pietro Gori, Neno Vasco, Gigi Damiani, Avellino Foscolo, Giovanni Baldi, Libero Pilotto, Jean Grave) e representado em italiano. O texto era fornecido em forma de libreto, publicado pela Livraria Teixeira-Vieira Pontes que chegou a organizar uma coleção especifica sob o nome de Biblioteca Dramática Popular. ${ }^{14}$

Seja atual ou histórico, o tema era comunicado sempre de forma didática e clara, cumprindo função adicional de manual de sobrevivência política para analfabetos. Autores, diretores, produtores e críticos parecem interessados muito mais no processo de emancipação da consciência de classe dos espectadores do que nos resultados estéticos das montagens. O estilo essencial dos personagens não exigiria dos intérpretes qualquer esforço ilusionista para capturar um público que, na grande maioria e antes da introdução do cinema, ignorava tal poder. Infelizmente não há fontes iconográficas que documentem as montagens. Todavia, a presença de carpinteiros, pintores e operários mecânicos nas trupes amadoras sugere que não fosse problema, somando competências, a fabricação de

${ }^{13}$ Um clássico era Francesca da Rimini, de Silvio Pellico cuja protagonista invoca: "Eu não tenho uma pátria que merece o sangue dos seus filhos? Só para ti, Itália minha pródiga de filhos, lutarei se a desonra me obrigar".

${ }^{14}$ Constam do catálogo da Livraria Teixeira (São Paulo): L'ideale e Senza Patria, de Pietro Gori; Semeador, de Avellino Foscolo; Ribellioni e Miseria, de Giovanni Baldi; Una commedia sociale, de C. Malato; Veterano della Libertà, de Baptista Diniz; Il prete garibaldino, de Libero Pilotto; L'assalto, de A. Traversi; Responsabilità, de Jean Grave; Avatar, de Marcelo Gama (em port.) e Canudos o Il buon Gesù de G.C. Camilli. Outras peças citadas por jornais não constam de nenhum arquivo: L'assalto, Tristi carnevali, Canti libertari e La tromba del giudizio, montados pelo Circolo Germinal, no Eden Club em 1907 e I carbonari del 1821, montado pelo Circolo Pietro Mascagni. Alguns destes dramas constam no segundo volume da antologia Teatro popolare (MOLINARI, 1907). 
praticáveis e telões pintados. O que resta dos espaços ${ }^{15}$ mostra tratar-se de auditórios dotados de um palco raso, sem profundidade suficiente para abrigar material cenográfico, sem coxias e sem parapeitos. Não há camarins nem urdimento, somente uma treliça capaz de suportar dois ou três telões, no máximo. Provavelmente alguns panos de fundo (um campestre, um urbano e outro clássico) eram adaptados para diferentes montagens; bem como os figurinos eram reciclados segundo um típico esquema binário (a dupla nobre/plebeu servindo para patrão/trabalhador) que reflete a estagnação política dos tempos.

Um tal movimento intelectual-teatral não passaria despercebido na paisagem culturalmente desinteressante da São Paulo da época. A escassez de documentos, devida ao fato de que arquivos e bibliotecas eram incendiados durante as batidas policiais e foram destruídas de modo sistemático pelo Estado Novo (VARGAS, 1980, p. 16) impede a devolução de toda a efervescência da cultura ítalo-paulista do começo do século XX. Entretanto, indícios estão impressos nas páginas de jornais de ampla circulação, como Fanfulla. ${ }^{16}$ Talvez por representar o órgão oficial da comunidade, já que se propunha a cumprir funções públicas essenciais, como a publicação de livros didáticos, dicionários e manuais para escolas italianas, o jornal modificou sua primeira legenda de "jornal político" na mais neutra "gazeta do povo" e talvez por isso, resultou menos vulnerável a ataques da polícia do que outros folhetos politizados (TRENTO, 1989, p. 17). O ideário socialista vinculava a emancipação da classe trabalhadora à instrução formal; a exclusão das crianças imigradas da educação pública brasileira era considerada uma forma explicita de discriminação e opressão à qual a comunidade reagia inaugurando suas próprias escolas. A primeira Scuola Sociale abriu as portas em 1887 (junto com a Hospedaria dos Imigrantes) atendendo aos 3413 meninos e 2608 meninas matriculados na primeira série (GHIRARDI, 1999, p. 308). Entre 1895 e 1919, surgiram cerca de 50 escolas italianas no território do Estado

${ }^{15}$ O Salão Celso Garcia, da Associazione dele Classi Laboriose, na Rua do Carmo 39 na Sé e o Salão da Sociedade Beneficiente Guglielmo Oberdan na Rua Brigadeiro Machado 5, no Brás (atual 71).

${ }^{16}$ Fanfulla começou a circular em 1893, ininterruptamente até 1965, chegando a distribuir 15.000 exemplares, segundo só ao maior jornal brasileiro da época, o Estado de São Paulo. O Estadão começou a circular em 1877, com nome A província de São Paulo; adotou o nome atual em 1890. 
(CAMPAGNANO BIGAZZI, 2006, p. 101). O modelo pedagógico adotado "tinha pouco a ver com a preservação da identidade italiana" (PECORELLI, 2018, p. 121); pelo contrário, as crianças representavam o avamposto dos processos de assimilação, sendo prioritário que se aprendesse a língua portuguesa. Eram admitidas nas noitadas teatrais, onde poderiam acontecer competições de ginástica, bingos e loterias gastronômicas, shows de música, declamação de poesias e experiências de hipnotismo e onde as crianças poderiam apresentar recitais, coros e até seus próprios espetáculos. ${ }^{17}$ Acompanhando tal modelo pedagógico, os jornais encorajavam a solidariedade entre oriundos de diversas regiões, na base da classe social; também (por exemplo Avanti!, fundado pelos socialistas imigrados) promoviam a difusão do português como ferramenta para defender-se da oligarquia no poder e participar da vida política, não enquanto etnia, mas enquanto classe.

$\mathrm{O}$ investimento em jornais, escolas e noitadas teatrais revela um plano de ocupação de território. O sonho da América se preenchia de conteúdos próprios, em sua maioria contrários aos conteúdos ditados pelos colonizadores, que haviam chegado a América antes e que agiam como classe dominante. A identificação dos imigrantes como classe operária, não mais como oriundos, alavancou a emancipação da comunidade às custas das diferenças regionais e do legado nacionalista que havia animado os primeiros fluxos de migrantes - exilados e patriotas. Ao invés disso, os operários ítalo-paulistas acabaram se identificando na fé anarquista, mesmo que graças a deus (como escreveu Zélia Gattai), vale dizer adotando uma ideologia sui generis capaz de sincretizar corpos estranhos como a fé católica. $\mathrm{O}$ conceito de caridade, declinada sob o lema do voluntariado e da solidariedade, era fundamental para agenciar as atividades dos clubes por meio da prática da ajuda mútua (mutuo soccorso). As entradas (que todos pagavam, mesmo os membros, financiadores ou artistas) faziam caixa para fins sociais como apoiar a família de um desempregado, facilitar o regresso de quem não se adaptasse, financiar os recursos de um hospital, publicar a primeira edição de um jornal, comprar livros para a "biblioteca moderna" e instrumentos para a banda filarmônica (SILVEIRA, 1976a).

${ }^{17}$ Os poemas eram "sobre a tirania czarista" ou sobre "a conquista do futuro". Em 25 jul. 1903, no Salão Ibach, se deu uma peça criada e interpretada por crianças, Proximustuus, de Pietro Gori. 
A invasão da polícia nessas tranquilas reuniões de famílias era truculenta e legitimava o crescente clima de violência xenofóbica que culminou na "caça aos italianos" que em 1896 revirou a cidade baixa. Tudo começou durante uma apresentação do Otelo em benefício do Hospital Italiano. Homens sem farda invadiram o teatro São José aos berros de "morte à Itália", insultaram a bandeira e seguiram impunes em direção à redação do Fanfulla, que pretendiam devastar. Houve reação nos bairros italianos; a multidão armou a defesa com barricadas nas quais atores da companhia de Giovanni Emanuel foram vistos içar a bandeira tricolor; a mobilização foi duramente reprimida pela polícia, deixando dez mortos e muitos feridos. $\mathrm{O}$ agente internacional da classe artística italiana, Iginio Polese, relatou com indignação o acidente em sua revista L'Arte Drammatica e entrevistou envolvidos. O ator Amerigo Guasti disse ter sido espancado pela própria polícia. Polese reivindicou justiça junto ao governo italiano, sugerindo interromper relações diplomáticas. Todavia, nada aconteceu; de modo que o agente comentou que nenhum governo "se interessa no destino dos comediantes" (L'Arte Drammatica, 24 out. 1896 e 29 ago. 1896). Em junho de 1902, a polícia irrompeu no Cassino Penteado no Brás, anexo à fábrica têxtil Penteado, quando se encenava o poema dramático Primo Maggio, de Pietro Gori (1892). O jornal $O$ amigo do povo publicou (em 21 de junho de 1902) a seguinte crônica:

Sábado passado no cassino [...] se ouvia atentamente e pacificamente [o poema] quando os guardiões da ordem burguesa vieram perturbar o sossego. Foram informados que era festa particular. Os homenzinhos forçaram entrada, irromperam mesmo de cavalaria e tudo, assustando mulheres e crianças; e mandaram parar a peça, após prender três camaradas: Torti, Marconi e Cerchiai. Um dos guardiões da desordem puxou uma faca como se alguém o estivesse atacando. Coitado. Nós aqui registramos este horror, sem mais comentários. ${ }^{18}$

Em São Paulo, assim como em Buenos Aires e outras metrópoles operárias, o Primeiro de Maio ${ }^{19}$ era celebrado com uma liturgia especial na qual o poema de Gori fazia função de Paixão de Cristo - sua leitura

\footnotetext{
${ }^{18}$ Tradução minha. Ver também VARGAS (1980, p. 17).

${ }^{19}$ Data instituída em 1890 pela Internacional Socialista em comemoração da trágica greve de Chicago de 01 maio 1866, pela jornada de 8 horas de trabalho, quando a intervenção policial causou um massacre.
} 
suscitava vivas reações. O Círculo La Battaglia programou em julho de 1905, no Salão Ibach, uma velada (ou seja, um programa sem hora para terminar) com o drama Senza Patria (três atos com intermezzi em versos martelianos), de Pietro Gori, entre duas palestras (uma sobre "A questão social" e outra sobre "O ciclo das guerras civis") seguidas por uma "farsa hilariante", loteria e baile; a festa foi interrompida pela polícia. Que estivesse aí para celebrar uma data litúrgica, dançar ou recitar um poema, qualquer pessoa presente em um clube durante uma velada poderia ser preso e ter sua reputação manchada pela aura subversiva que caracterizava os anarquistas. $\mathrm{O}$ simples fato de estar no teatro era considerado suspeito.

\section{$* * * * *$}

O elenco de Senza Patria conta com personagens não qualificados por evolução psicológica, mas por representar forças sociais que lutam a favor ou contra a ideologia burguesa, opondo-se um ao outro por força de monólogos antagônicos. São eles: um velho agricultor já militante garibaldino, um marinheiro, sua filha, sua mãe, um jovem agricultor, um carreteiro. Já os personagens do Primo Maggio são: um proprietário de terra opressor, um velho agricultor que aceita a opressão vigente, um operário, um marinheiro e uma jovem camponesa que querem liberdade e um estrangeiro, agente da transformação. Evocando toda a potência ideológica do internacionalismo em discursos cuja retórica lembra a do estudante Trofimov no Jardim das cerejeiras, de Tchecov (escrito em 1904), o estrangeiro profetiza a decomposição do sistema como um todo e o advento do mundo novo:

Está lá... para o lado de onde o sol nasce... o país feliz... a terra pertence a todos, assim como o ar, a luz. Os homens lá são irmãos. O trabalho é brasão da nobreza para o povo... A única lei é a liberdade... o único vínculo é o amor... há conforto para todos... para todos a ciência. A mulher não é escrava, mas a companheira do homem. A miséria é desconhecida... A igualdade garantida pela harmonia dos direitos... não há parasitas, nem armados, nem guerras... as mães são serenas! Os velhos são mestres da infância... as crianças são educadas no trabalho e no amor ao próximo... a juventude é abençoada, como vanguarda pacífica do futuro... caminhemos... caminhemos! É lá, o país feliz... lá, onde o sol nasce. (GORI, 1923, p. 34). 
O contexto em volta dele, porém, permanece imóvel, até porque ele evita encarar os senhores locais. Sua função é de deus ex machina: as transformações que aciona são mágicas, visando um final feliz que o enredo não sustenta. Em Semeador, de Avellino Foscolo, esta mesma função é atribuída ao filho do fazendeiro, regresso dos estudos na Europa. Ao invés de assumir seu lugar em força de sua herança e diploma, ele se esforça em vencer a resistência da sua classe com seu projeto cooperativo a favor dos oprimidos - que acaba triunfando, porque o pai morre e ele se torna patrão. O gênero ainda se encaixa nos parâmetros melodramáticos, onde bem e mal duelam sob vestes alegóricas, muitas vezes multiplicando tal esquema binário em duplas por idade (o galã normalmente é novo, enquanto o vilão é velho) ou por classe. O herói oprimido é levado pelo opressor (normalmente um antológico cafajeste) ao limite de sua resistência, ameaçando explodir a qualquer hora; o que provoca empatia no público e uma crescente indignação pelas maquiavélicas injustiças das quais padece. O sistema acaba sendo descrito e condenado mais pelos atos voluntários de um sujeito mau do que como mecanismo de exploração. Não dir-se-ia uma dramaturgia épica se não aparecesse, excepcionalmente, um personagem raiseunneur para comentar a ação sem desempenhar função dramática alguma, mas provocando a reflexão e expandindo o debate à plateia. É o caso do jornalista (em Responsabilità, de Jean Grave) que acompanha a difícil escolha de um trabalhador entre militância sindical e sobrevivência dos filhos. Outro caso é do papel desempenhado pelo anarquista Gigi Damiani, o qual, na encenação de dramas de sua autoria (Repubblica, Osteria della Vittoria) costumava subir ao palco e comentar ao vivo o andamento da peça, com sua jaqueta roxa e chapéu borsalino. Intuitos didáticos permeiam a peça em um ato Una commedia sociale, de Malato, ambientada em uma Londres alegórica. Um desempregado, ao pedir esmola, é insultado por um senhor burguês, bem na hora da passagem de um jovem anarquista. Este acusa o desempregado de humilhar a classe e o burguês de explorá-la. Chega a polícia. $\mathrm{O}$ anarquista convence os guardas que convém proteger o pobre, já que ricos são poucos. O final feliz, mesmo que um tanto inconsequente, é garantido - afinal a peça é anunciada como "comédia".

Autores paulistas muito prolíficos como Marino Spagnolo escrevem dramas em italiano inspirados nas lutas do Risorgimento (Militarismo e miséria, Teseo, Alba) e nas lutas pelos direitos dos trabalhadores (Bandiera proletaria). Mais raramente a discussão envolvia 
fatos da história brasileira, como no "grandioso drama" intitulado Il buon Gesù e dedicado em 1897 ao massacre de Canudos por um jornalista ítalo-paulista, G.C. Camilli, casado com a atriz Elvira Camilli. A peça, escrita em italiano, é montada "ricamente" no Teatro Politeama pela companhia profissional Tiozzi-Cuneo, com o primeiro ator no papel do coronel do exército republicano e a mulher do autor contratada para a ocasião, a peça era finalizada por uma "apoteose" representando o triunfo da jovem República sobre seus inimigos. Tratava-se, no caso, da chacina de uma população indefesa. Foi muito pateada na estreia e a imprensa polemizou. "Não é o primeiro assassinato dramático do nosso Camilli”, comenta Fanfulla. ${ }^{20}$. Enquanto a cabeça do verdadeiro Antonio Conselheiro, decapitada e transportada da Bahia ao Rio de Janeiro pelo Primeiro Batalhão do Exército, era submetida a autópsia para que se revelasse qual patologia poderia ter detonado a exaltação que "custou tantos sacrifícios à jovem República" 21 , o personagem Conselheiro, interpretado por Angelo Pezzoini, recolhia ovações em cena.

Ascendendo na consideração do público burguês, o teatro amador perdia seus traços rebeldes enquanto conquistava patronos mais endinheirados e locais melhor equipados. Em 1901, o farmacêutico Ernesto Materasso transformou um armazém de sua propriedade na Rua dos Imigrantes em uma sala teatral que "nossa sociedade nunca tinha possuído nem sonhado possuir", relata o Fanfulla..$^{22}$ Em 1902, Camilli lançou I Napolitani al Brasile, um drama inédito sobre imigração, no Eden Club, na rua Florêncio de Abreu. A mística do Brasil como "terra prometida" mostra o esforço que a burguesia, quatrocentona e mesmo ítalo-paulista, estava fazendo para apropriar-se daquela tradição teatral e daquele público. Em 1903, a Companhia de Teatro Popular de Enrico Cuneo montou Hamlet e obtém uma sede estável, na Rua do Gasômetro, onde apresenta repertório ambicioso no qual alterna Shakespeare (Romeo e Julieta e outros) com dramas políticos e históricos (Galileo dinanzi all Inquisizione, de Monticini; Os Miseráveis, de Victor Hugo).

\footnotetext{
${ }^{20}$ Não foi possível recuperar nenhuma outra informação de referência a respeito do trecho citado, apenas que apareceu na revista Fanfulla de 27 de outubro de 1897.

${ }^{21}$ Ver a nota de rodapé anterior.

${ }^{22}$ O trecho citado foi encontrado na obra de Silveira (1976a, p. 75), sem que fosse possível recuperar nenhuma outra informação de referência, apenas que apareceu na revista Fanfulla de 12 de agosto de 1901.
} 
Em setembro de 1905, o jornal italiano L'Indipendente organizou um concurso entre amadores com menções honrosas para os Círculos concorrentes (Andrea Maggi, Ermete Novelli, L'Avvenire, Amor dell'Arte, Ermete Zacconi, Mafalda di Savoia) e distribuição de medalhas para atores e atrizes, cuja receita foi destinada em benefício das vítimas do terremoto na Calábria. Fanfulla (20 set. 1905) comentou estar lotadíssima a sessão da Morte Civile pelo Círculo Andrea Maggi. O empresário salernitano Pascoal Segreto, desembarcado no Rio com quinze anos em 1884 e, nesta altura, dono da noite carioca com suas sete casas de espetáculo, reversíveis para cinema, contribuiu à campanha com parte da bilheteria da revista musical em cartaz no fabuloso Teatro Carlos Gomes, no Rio de Janeiro. Não surpreende que, quarenta anos mais tarde (1947), seja iniciativa de um imigrante napolitano bem-sucedido por sua carreira como capitão de indústria, Franco Zampari, a fundação de um teatro que o empresário literalmente presenteou aos amadores de São Paulo: o Teatro Brasileiro de Comédia. Mas esta é outra história (VANNUCCI, 2014).

Em 1907, dois anos antes que pudesse ser inaugurado o Teatro Municipal, cuja problemática construção durou 15 anos, no Largo da Concórdia, no bairro do Brás, inaugurou-se o Teatro Colombo, com quase 2000 lugares (dos quais 260 em pé) e a melhor acústica da cidade. O repórter do Commercio de São Paulo o descreveu como "um espaço muito confortável e elegante que seria bem mais adequado à outra área da cidade e outra gente, quero dizer gente mais fina, daqui de cima". ${ }^{23}$ Será palco para muitas trupes amadoras; nele se consagrará uma futura grande atriz, Faustina Polloni, cujo percurso surge e se firma no âmbito filodrammatico.

\section{$* * * * *$}

Era nascida em Verona, na Itália, em 1884; mas naturalizada brasileira lavrando, anos depois, um documento falso que postergava seu nascimento a 1890, já no Brasil, protegendo-a do fato de que ser

${ }^{23}$ O trecho citado foi encontrado na obra de Silveira (1976a, p. 120), sem que fosse possível recuperar nenhuma outra informação de referência, apenas que apareceu no jornal Commercio de São Paulo. 
estrangeira poderia significar uma maior vulnerabilidade social. ${ }^{24}$ Inscreveu, contudo, a nacionalidade no nome artístico: Itália Fausta.

Entrou em cena ainda criança, com a irmã Carmela, porque moravam no prédio que hospedava o Eden Club. Com quatorze anos, em 1899, contracenou com a consagrada Clara della Guardia. A partir de 1901 foi atriz disputada por diversas companhias filodramáticas, destacando-se em papéis fortes como Lo schiavo di San Domingo de Colajanni (25 mar. 1901), Tosca de Sardou (3 maio 1901), Rui Blas de Hugo (14 jul. 1902), Il ricordo di una notte nel Golfo d'Ischia, de Dumas (02 fev. 1903), Riabilitazione di un forzato, de Filippo Falchi (30 mar. 1903), Francesca da Rimini, de Silvio Pellico (20 abr. 1903), I masnadieri, de Schiller (24 jan. 1904). Assinou seu primeiro contrato profissional em 1904, com Enrico Cuneo, cujo Teatro Popular tinha sede permanente no Cassino Penteado, abandonando seu emprego de operária têxtil - também era chefe de sua secção sindical. Atuou como "dama jovem" nas companhias portuguesas de Lucinda Simões e do Cristiano de Souza, com os quais excursionou pelo Brasil e, em 1913, por Portugal; até fundar sua própria companhia. Era alta e imponente, com a voz impostada e um temperamento forte.

Realizou projetos ousados, como o Teatro da Natureza que encenou tragédias clássicas e melodramas para um público de vinte mil espectadores no Campo de Santana, no Rio de Janeiro. Na década de 40, em seus sessenta anos, envolveu-se com uma companhia de jovens sonhadores que trabalhavam um repertório moderno dirigidos por um italiano recém-chegado de Milão - Ruggero Jacobbi. ${ }^{25}$ Era o Teatro Popular de Arte, com Maria della Costa como atriz jovem e Sandro Polloni (sobrinho de Itália) como empresário. Para resistir à desocupação do Teatro Phenix, no Rio de Janeiro, que o proprietário pretendia destinar a outro uso, Itália dormiu 12 noites no tablado com sua trupe; sua pertinácia comoveu a opinião pública e ficaram. No ano seguinte, apresentou no palco do Teatro Municipal de São Paulo, que a homenageava por seu jubileu. Bairro República, cidade alta.

\footnotetext{
${ }^{24}$ Mesmo radicados no Brasil, artistas estrangeiros não poderiam usufruir das verbas destinadas à comemoração do centenário da Independência, em 1922 (cf. Brandão, 2000, p. 301).

${ }^{25}$ Em Milão, Jacobbi havia participado da fundação do Piccolo Teatro, o primeiro teatro estável e público italiano, inteiramente bancado pela municipalidade socialista.
} 
A consagração de sua carreira como atriz dramática naquele templo da ópera lírica por si só destituía as fronteiras sociais aparentemente intransponíveis que, durante meio século, haviam dividido a metrópole, pelos rios, em duas nações antagônicas. Interrompendo as palmas, Itália discursou sobre suas origens. Desde o dia em que havia deixado a fábrica pelo teatro, disse, trabalhava como qualquer operária: sendo remunerada, entendia que seu ofício tinha as mesmas obrigações éticas de qualquer outro. Orgulhava-se de ser uma "trabalhadora do palco". Faleceu dois anos mais tarde. "A nova geração", comentou um crítico, "não poderia encontrar melhor exemplo do que sua permanente ânsia de aperfeiçoamento" (SILVEIRA, 1976b, p. 293).

\section{Referências}

BASSANEZI, Maria Silvia C. Beozzo (org.). São Paulo do passado. Dados demográficos. Campinas: Núcleo de Estudos de População, 1999. Disponível em: http://www.nepo.unicamp.br/publicacoes/censos/1920. pdf. Acesso em: 25 jul. 2019.

BRANDÃO, Tania. Teatro Brasileiro no Século XX: origens e descobertas, vertiginosas oscilações. Revista do Iphan, Rio de Janeiro, n. 29, p. 301-335, 2000.

CAMPAGNANO BIGAZZI, Anna Rosa. Imigrantes no Brasil: italianos: história e memória de uma comunidade. São Paulo: Companhia Editora Nacional, 2006.

CAPPELLI, Vittorio. Pequenas pátrias, a pátria, outras pátrias: as complexas identidades dos italianos no Brasil e na América latina. Naveg@merica, Múrcia, n. 13, p. 1-14, 2014.

CARELLI, Mario. Carcamanos e comendadores: os italianos de São Paulo (1919-1930). São Paulo: Ática, 1985.

COSTA, Rovilio; DE BONI, L. Alberto (org.). La presenza italiana nella storia e nella cultura del Brasile. Torino: Ed. Giovanni Agnelli, 1987.

GHIRARDI, Pedro Garcez. Notas sobre a literatura da imigração italiana em São Paulo. In: BÓ, Juventino Dal; IOTTI, Luiza Horn; MACHADO, Maria Beatriz Pinheiro. Imigração italiana e estudos ítalo-brasileiros. 
Anais do Simpósio Internacional sobre Imigração Italiana e IX Fórum de Estudos Ítalo-brasileiros. Caxias do Sul: EDUCS, 1999. p. 307-316. GORI, P. Il Primo Maggio. Santos: Biblioteca Cosmos, 1923.

HALL, Michael. O movimento operário na cidade de São Paulo, 18901954. In: PORTA, Paula (org.). História da cidade de São Paulo: A cidade na primeira metade do século XX, 1890-1954. Rio de Janeiro: Paz e Terra, 2004. v. 3.

HUTTER, Lucy Maffei. Imigração italiana em São Paulo (1902-1914). São Paulo: Instituto de Estudos Brasileiros da Universidade de São Paulo, 1986.

LESSA MATTOS, David José. O espetáculo da cultura paulista: Teatro e TV em São Paulo 1940- 1950. São Paulo: Códex, 2002.

MACHADO, Antônio de Alcântara. Palcos em foco: crítica de espetáculos / Ensaios sobre teatro (1923-1933). São Paulo: Editora da Universidade de São Paulo, 2009.

MAGALDI, Sabato; VARGAS, M. Teresa. Cem anos de teatro em São Paulo. São Paulo: Senac, 2000.

MARZOLA, Nádia. Bela vista: história dos bairros de São Paulo. Prefeitura do Município de São Paulo, 1979.

MAURO, Fréderic. O Brasil no tempo de Dom Pedro II. São Paulo: Companhia das Letras, 1980.

MAZZINI, Giuseppe. Nazionalità. Qualche idea su una costituzione nazionale. In: MAZZINI, G. Edizione nazionale degli scritti. Imola: Galeati, 1906. v. VI.

MOLINARI, Luigi. Teatro popolare. Milano: Tipografia dell'Università Popolare, 1907. v. II.

PECORELLI, Joseph. Literature and the immigrant experience: the social integration and ascension of italians in Brazil. 2018. Tese (Doutorado em Filosofia) - Department of Spanish and Portuguese, Indiana University, Bloomington, 2018.

SILVEIRA, Miroel. A contribuição italiana ao teatro brasileiro. São Paulo: Queiron Limitada, 1976a. 
SILVEIRA, Miroel. A outra crítica. São Paulo: Símbolo, 1976 b.

TRENTO, Angelo. Cultura, instrução e teatro operário. In: TRENTO, A. Do outro lado do Atlântico. São Paulo: Nobel, 1989. p. 251-255.

VANNUCCI, Alessandra (org.) Uma amizade revelada: Correspondência entre o Imperador D. Pedro II e Adelaide Ristori, a maior atriz de seu tempo. Rio de Janeiro: Ed. Biblioteca Nacional, 2005.

VANNUCCI, Alessandra. A missão italiana. São Paulo: Perspectiva, 2014.

VANNUCCI, Alessandra. Artistas estrangeiros no Brasil. In: FARIA, J.R. (org.). História do teatro brasileiro. São Paulo: Perspectiva, 2012. V. 1, p. 275-295.

VANNUCCI, Alessandra. Le compagnie viaggianti: Mattatori e primedonne che infiammarono il Brasile. Letterature d'America, Roma, ano XXIII, n. 97, 2003, p. 71-126.

VARGAS, Maria Teresa (org.). Teatro operário na cidade de São Paulo. São Paulo: Secretaria Municipal de Cultura, Departamento de Informação e Documentação Artísticas, Centro de Pesquisa de Arte Brasileira, 1980.

Recebido em: 3 de fevereiro de 2019. Aprovado em: 3 de junho de 2019. 